\title{
Adoption of Improved Dairy Farming Practices by Dairy Farmers of Haryana, India
}

\author{
Manish Kumar Singh ${ }^{1}$, Awadhesh Kumar Singh ${ }^{2 *}$ and K.S. Kadian ${ }^{3}$ \\ ${ }^{1}$ Department of Agriculture, Mata Gujri College, Shri Fatehgarh Sahib, Punjab-140407, India \\ ${ }^{2}$ Raja Dinesh Singh Krishi Vigyan Kendra, Ainthu, Lalabazar, Kalakankar, Pratapgarn, \\ UP-229408, India \\ ${ }^{3}$ Dairy Extension Division, NDRI, Karnal, Haryana, India \\ *Corresponding author
}

\section{A B S T R A C T}

\section{Key w o r d s \\ Adoption, Breeding, Feeding, \\ Management, Improved practices \\ Article Info \\ Accepted: \\ 24 August 2018 \\ Available Online: \\ 10 September 2018}

Study was conducted in Haryana to assess the extent of adoption of improved dairy farming practices by the selected dairy farmers. The data were collected from four agroclimatic zone of Haryana. From each zone one district was selected purposively on the basis of milch animal population. Then from each district two blocks were selected randomly. From each block two villages were selected randomly. From each village 15 dairy farmers were selected randomly. Thus, in total, 240 dairy farmers were selected, as the respondents for this study with the help of structure interview schedule. From the study it was observed that majority of the respondents $(66.25 \%)$ had medium level of adoption of breeding practices. In case of feeding practices majority of the respondents $(68.34 \%)$ fell in medium level. Regarding healthcare practices most of the respondents $(70.83 \%)$ were observed in medium category. As for as concerned, the management practices majority of the respondents $(51.25 \%)$ in medium category. Regarding healthcare practices most of the respondents $(70.83 \%)$ were observed in medium category. Majority of the respondents $(62.09 \%)$ had medium level of overall adoption of improved dairy farming practices.

\section{Introduction}

Dairy farming is one of the important income generating activities of the rural population of our country. Milk production during 1950-51 was estimated at 17 million tonnes which rose to 132.4 million tonnes in 2013-14 and per capita availability of milk during 1951 was $132 \mathrm{gm}$ which increased to $290 \mathrm{gm}$ in 2013-14 (Department of Animal Husbandry, Dairying \& Fisheries, Ministry of Agriculture, GoI). More than 70.00 per cent Indian rural households own livestock and majority of them are with less than 5 dairy animals, particularly cow and buffaloes and derive supplementary income and nutrition by producing milk for self-consumption and for sale in the market (Birthal and Jha 2005).

India has the largest cattle and buffalo population in the world and is also the single largest milk producing country but the productivity per animal is amongst the lowest in the world. Livestock sector contribute 3.2 
percent value of total GDP, whereas Agriculture contribution in total GDP is 15.18 percent (National Accounts Statistics, Central Statistical Organisation, GoI, 2013). In India, milk production contributes on an average 27 percent of the household income, its contribution varies from about 19 percent in the case of large farmers to about 53 percent in the landless category (Shukla and Brahmankar, 1999).

Nearly two thirds of farm households in India are associated with one or the other form of livestock production and 80 percent of them are small landholders (< 2ha), livestock contribute substantially to their livelihood and provides coping mechanism during the period of crop failure. Therefore, the present investigation was undertaken with following objectives:

To elicit the extent of adoption of improved dairy farming practices among the respondents

\section{Materials and Methods}

Study was conducted in purposively selected four agro-climatic zones of Haryana, namely, Northern, Southern, Central and Western zone. From each zone one district was selected purposively on the basis of milch animal population. From each district two blocks were selected randomly. From each block two villages were selected randomly. From each village 15 dairy farmers were selected randomly.

Thus, in total, 240 dairy farmers were selected, as the respondents for this study. In the present study adoption was measured by collecting all the relevant items related to recommend dairy farming practices by NDRI and NABARD, with consultation of scientists from NDRI, and veterinarians in the study area, and also concerned literature and previous research studies. The selected items were divided in following heads: feeding, breeding, health care and management practices. The response of the respondents were taken against each of the practice on a three point continuum representing adoption Always, Sometime and Never with scores of 2,1 and 0 respectively.

The respondents were categorized into low, medium and high categories of adoption on the basis of mean and standard deviation of score in different aspects of adoption as well as overall adoption of improved dairy farming practices. The following formula was used to measure the adoption index of different aspects of improved dairy farming practices.

Score obtained by an individual

Adoption Index =

Maximum obtainable score

\section{Results and Discussion}

Distribution of respondents as per level of adoption of improved breeding practices

The analysis of 240 respondents regarding breeding practices (Table 1) revealed that the first rank was given to appropriate period of A.I. after calving with adoption score of 395. While adoption of A.I. practices and watching on estrous cycle and heat symptoms were obtained $2^{\text {nd }}$ and $3^{\text {rd }}$ rank with adoption score of 393 and 383 respectively. Pregnancy diagnosis (379), help taken from veterinarian during parturition (365) and right time of A.I. after heat (331) were awarded $4^{\text {th }}, 5^{\text {th }}$ and $6^{\text {th }}$ ranks, respectively. While the last rank was awarded to checking of buffalo during pregnancy (285).

It may be concluded that high adoption of appropriate period of A.I. and watching on oestrous cycle and heat symptoms by the respondents may be due to the fact that the respondents have more knowledge about these 
practices because these practices are very essential in cattle rearing. Poor adoption of pregnancy checking in cattle was observed among the respondents because in some cases farmer even do not allow to touch the reproductive organs of his animal due to their ignorance about these practices. Raisen (1994) and Menon (2009) also reported the same result.

Distribution of respondents as per level of adoption of improved feeding practices

The analysis of 240 respondents (Table 2) observed that the first rank was awarded to colostrums feeding with highest adoption score of (426). Similarly, continuous feeding of colostrums (410), chaffing of green fodder (393), feeding of concentrate mixture to animal on the basis of milk production (390), regular feeding of recommended green fodder to animal (386) and application of recommended dose of manure and fertilizers in the fodder crops (376) were occupied the ranks of $2^{\text {nd }}, 3^{\text {rd }}, 4^{\text {th }}$ and $5^{\text {th }}$, respectively. Among all the eleven feeding items, the lowest adoption was recorded by the respondents regarding feeding of prepared hay (278).

The results so appeared may be due to the fact that farmers know the importance of colostrums feeding to newly born calf because it develops antibodies and laxative for newly born calf. Whereas the farmers are not given priority to preparation of hay due to unawareness about importance and method of hay making. These results are supported by the observation of Srivastava et al., (2010) and Shinde et al., (2001).

Distribution of respondents as per level of adoption of improved health care practices

It is observed from the data given in Table 3 regarding adoption of all the nine health care practices that cattle owners had vaccinated their animals to control F.M.D. at proper time and accordingly this practices was found to have the highest adoption score (440) followed by timely treatment of sick and weak animal by Veterinary Doctors (430) and Timely vaccination of H.S. (418), respectively. Similarly, protection of animals from severe cold (405), segregation of diseased animals suffering from contagious diseases (403), treatment of sick animals/repeat breeders and anoestrus by veterinary doctors (400).

Among all the nine health care items, the lowest adoption was recorded by the respondents regarding burying of the dead body of animals dies of contagious diseases (392), segregation of sick animals from healthy ones (390) and applying of pesticides for prevention of ticks and mites (342).

From the above mention results, it can be concluded that timely vaccination of F.M.D. was found to have highest adoption score and placed on first priority which might be due to the fact that farmers are more attentive for taking care of their animal against F.M.D. whereas the farmers were least bothered about ticks and mites. So, adoption of this practice was found low. These findings are in line with the findings of Lomani (1996), Shukla and Pathak (1995), Shiraj (2000) and Srivastava et al., (2010).

\section{Distribution of respondents as per level of adoption of improved management practices}

The response of 240 respondents were recorded the adoption of management practices (Table 4). Keeping of animals in ventilated house was found to have maximum adoption score i.e. 439 followed by adequate water facility and feed to the animal (432) and adequate open space for the animal (418). 
Table.1 Distribution of respondents as per level of adoption of improved breeding practices

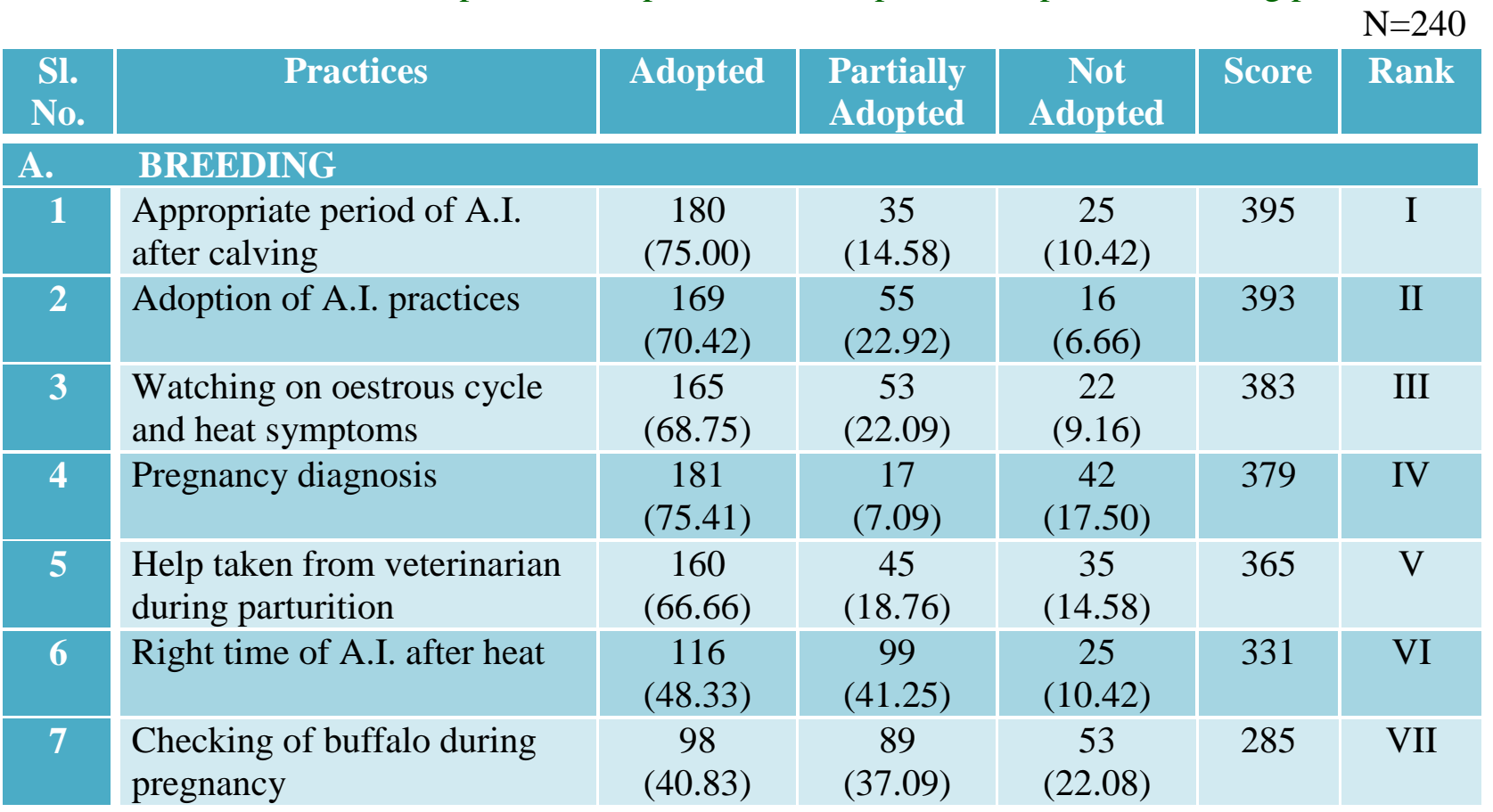

Figures in parentheses indicate percentage

Table.2 Distribution of respondents as per level of adoption of improved feeding practices

\begin{tabular}{|c|c|c|c|c|c|c|}
\hline & & & & & & $=240$ \\
\hline $\begin{array}{l}\text { Sl. } \\
\text { No. }\end{array}$ & Practices & Adopted & $\begin{array}{l}\text { Partially } \\
\text { Adopted }\end{array}$ & $\begin{array}{c}\text { Not } \\
\text { Adopted }\end{array}$ & Score & Rank \\
\hline B. FE & DING & & & & & \\
\hline 1 & Colostrums feeding & $\begin{array}{c}200 \\
(83.34)\end{array}$ & $\begin{array}{c}26 \\
(10.83)\end{array}$ & $\begin{array}{c}14 \\
(5.83)\end{array}$ & 426 & I \\
\hline 2 & Continuous feeding of colostrums & $\begin{array}{c}183 \\
(76.25)\end{array}$ & $\begin{array}{c}44 \\
(18.33)\end{array}$ & $\begin{array}{c}13 \\
(5.42)\end{array}$ & 410 & II \\
\hline 3 & Chaffing of green fodder & $\begin{array}{c}179 \\
(74.58)\end{array}$ & $\begin{array}{c}35 \\
(14.58)\end{array}$ & $\begin{array}{c}26 \\
(10.84)\end{array}$ & 393 & III \\
\hline 4 & $\begin{array}{l}\text { Feeding concentrate mixture to animal on } \\
\text { the basis of milk production }\end{array}$ & $\begin{array}{c}168 \\
(70.00)\end{array}$ & $\begin{array}{c}54 \\
(22.50)\end{array}$ & $\begin{array}{c}18 \\
(7.50)\end{array}$ & 390 & IV \\
\hline 5 & $\begin{array}{l}\text { Regular feeding of recommended green } \\
\text { fodder to animal }\end{array}$ & $\begin{array}{c}170 \\
(70.83)\end{array}$ & $\begin{array}{c}46 \\
(19.17)\end{array}$ & $\begin{array}{c}24 \\
(10.00)\end{array}$ & 386 & $\mathrm{~V}$ \\
\hline$\overline{6}$ & $\begin{array}{l}\text { Application of recommended dose of } \\
\text { manure and fertilizers in the fodder crops }\end{array}$ & $\begin{array}{c}162 \\
(67.50)\end{array}$ & $\begin{array}{c}52 \\
(21.66)\end{array}$ & $\begin{array}{c}26 \\
(10.84)\end{array}$ & 376 & VI \\
\hline 7 & Regular grazing & $\begin{array}{c}120 \\
(50.00)\end{array}$ & $\begin{array}{c}100 \\
(41.66)\end{array}$ & $\begin{array}{c}20 \\
(8.34)\end{array}$ & 340 & VII \\
\hline 8 & $\begin{array}{l}\text { Feeding advance pregnant buffalo with } \\
\text { extra concentrate }\end{array}$ & $\begin{array}{c}104 \\
(43.33)\end{array}$ & $\begin{array}{c}80 \\
(33.33)\end{array}$ & $\begin{array}{c}56 \\
(23.34)\end{array}$ & 288 & VIII \\
\hline 9 & Feeding of mineral mixture & $\begin{array}{c}120 \\
(50.00)\end{array}$ & $\begin{array}{c}43 \\
(17.91)\end{array}$ & $\begin{array}{c}77 \\
(32.09)\end{array}$ & 283 & IX \\
\hline 10 & $\begin{array}{l}\text { Cultivation of high yielding varieties of } \\
\text { fodder }\end{array}$ & $\begin{array}{c}110 \\
(45.83)\end{array}$ & $\begin{array}{c}60 \\
(25.00)\end{array}$ & $\begin{array}{c}70 \\
(29.17)\end{array}$ & 280 & $\mathrm{X}$ \\
\hline 11 & Feeding of prepared hay & $\begin{array}{c}94 \\
(39.16)\end{array}$ & $\begin{array}{c}90 \\
(37.50)\end{array}$ & $\begin{array}{c}56 \\
(23.34)\end{array}$ & 278 & XI \\
\hline
\end{tabular}

Figures in parentheses indicate percentage 
Table.3 Distribution of respondents as per level of adoption of improved health care practices

\begin{tabular}{c|c|c|c|c|c|c|}
$\begin{array}{c}\text { S. } \\
\text { No. }\end{array}$ & Practices & Adopted & $\begin{array}{c}\text { Partially } \\
\text { Adopted }\end{array}$ & $\begin{array}{c}\text { Not } \\
\text { Adopted }\end{array}$ & Score & Rank \\
\hline C. HIEALTH CA RE & &
\end{tabular}

\section{HEALTH CARE}

\begin{tabular}{|c|c|c|c|c|c|c|}
\hline 1 & $\begin{array}{l}\text { Timely vaccination of } \\
\text { FMD }\end{array}$ & $\begin{array}{c}213 \\
(88.75)\end{array}$ & $\begin{array}{c}14 \\
(5.82)\end{array}$ & $\begin{array}{c}13 \\
(5.43)\end{array}$ & 440 & I \\
\hline 2 & $\begin{array}{l}\text { Timely treatment of } \\
\text { sick and weak animal } \\
\text { by Veterinary Doctors }\end{array}$ & $\begin{array}{c}205 \\
(85.42)\end{array}$ & $\begin{array}{c}20 \\
(8.33)\end{array}$ & $\begin{array}{c}15 \\
(6.25)\end{array}$ & 430 & II \\
\hline 3 & $\begin{array}{l}\text { Timely vaccination of } \\
\text { H.S. }\end{array}$ & $\begin{array}{c}190 \\
(79.17)\end{array}$ & $\begin{array}{c}38 \\
(15.83)\end{array}$ & $\begin{array}{c}12 \\
(5.00)\end{array}$ & 418 & III \\
\hline 4 & $\begin{array}{l}\text { Protection of animals } \\
\text { from severe cold }\end{array}$ & $\begin{array}{c}185 \\
(77.09)\end{array}$ & $\begin{array}{c}35 \\
(14.58)\end{array}$ & $\begin{array}{c}20 \\
(8.33)\end{array}$ & 405 & IV \\
\hline 5 & $\begin{array}{l}\text { Segregation of } \\
\text { diseased animals } \\
\text { suffering from } \\
\text { contagious diseases }\end{array}$ & $\begin{array}{c}174 \\
(72.50)\end{array}$ & $\begin{array}{c}55 \\
(22.92)\end{array}$ & $\begin{array}{c}11 \\
(4.58)\end{array}$ & 403 & V \\
\hline 6 & $\begin{array}{l}\text { Treatment of sick } \\
\text { animals/repeat breeders } \\
\text { and anoestrus by } \\
\text { veterinary doctors }\end{array}$ & $\begin{array}{c}180 \\
(75.00)\end{array}$ & $\begin{array}{c}40 \\
(16.66)\end{array}$ & $\begin{array}{c}20 \\
(8.34)\end{array}$ & 400 & VI \\
\hline$\overline{7}$ & $\begin{array}{l}\text { Burying of the dead } \\
\text { body of animals dies of } \\
\text { contagious diseases }\end{array}$ & $\begin{array}{c}188 \\
(78.34)\end{array}$ & $\begin{array}{c}16 \\
(6.66)\end{array}$ & $\begin{array}{c}36 \\
(15.00)\end{array}$ & 392 & VII \\
\hline 8 & $\begin{array}{l}\text { Segregation of sick } \\
\text { animals from healthy } \\
\text { ones }\end{array}$ & $\begin{array}{c}169 \\
(70.42)\end{array}$ & $\begin{array}{c}52 \\
(21.66)\end{array}$ & $\begin{array}{c}19 \\
(7.92)\end{array}$ & 390 & VIII \\
\hline 9 & $\begin{array}{l}\text { Applying of pesticides } \\
\text { for prevention of ticks } \\
\text { and mites etc. }\end{array}$ & $\begin{array}{c}120 \\
(50.00)\end{array}$ & $\begin{array}{c}102 \\
(42.50)\end{array}$ & $\begin{array}{c}18 \\
(7.50)\end{array}$ & 342 & IX \\
\hline
\end{tabular}

Figures in parentheses indicate percentage 
Table.4 Distribution of respondents as per level of adoption of improved management practices

\begin{tabular}{|c|c|c|c|c|c|c|}
\hline $\begin{array}{l}\text { Sl. } \\
\text { No. }\end{array}$ & Practices & Adopted & $\begin{array}{l}\text { Partially } \\
\text { Adopted }\end{array}$ & $\begin{array}{c}\text { Not } \\
\text { Adopted }\end{array}$ & Score & Rank \\
\hline \multicolumn{7}{|c|}{ D. MANA GEMENT } \\
\hline 1 & $\begin{array}{l}\text { Keeping of animals in } \\
\text { ventilated house }\end{array}$ & $\begin{array}{c}212 \\
(88.33)\end{array}$ & $\begin{array}{c}15 \\
(6.25)\end{array}$ & $\begin{array}{c}13 \\
(5.42)\end{array}$ & 439 & I \\
\hline 2 & $\begin{array}{l}\text { Adequate water } \\
\text { facility and feed to the } \\
\text { animal }\end{array}$ & $\begin{array}{c}206 \\
(85.83)\end{array}$ & $\begin{array}{c}20 \\
(8.34)\end{array}$ & $\begin{array}{c}14 \\
(5.83)\end{array}$ & 432 & II \\
\hline 3 & $\begin{array}{l}\text { Adequate open space } \\
\text { for the animal }\end{array}$ & $\begin{array}{c}190 \\
(79.16)\end{array}$ & $\begin{array}{c}38 \\
(15.84)\end{array}$ & $\begin{array}{c}12 \\
(5.00)\end{array}$ & 418 & III \\
\hline 4 & $\begin{array}{l}\text { Wallowing of animal } \\
\text { in pond }\end{array}$ & $\begin{array}{c}184 \\
(76.67)\end{array}$ & $\begin{array}{c}35 \\
(14.58)\end{array}$ & $\begin{array}{c}21 \\
(8.75)\end{array}$ & 403 & IV \\
\hline 5 & $\begin{array}{l}\text { Practicing de-worming } \\
\text { in calf }\end{array}$ & $\begin{array}{c}173 \\
(72.09)\end{array}$ & $\begin{array}{c}55 \\
(22.91)\end{array}$ & $\begin{array}{c}12 \\
(5.00)\end{array}$ & 401 & $\mathrm{~V}$ \\
\hline 6 & $\begin{array}{l}\text { Help taken from } \\
\text { veterinarians during } \\
\text { the sickness of animals }\end{array}$ & $\begin{array}{c}188 \\
(78.34)\end{array}$ & $\begin{array}{c}22 \\
(9.16)\end{array}$ & $\begin{array}{c}30 \\
(12.50)\end{array}$ & 398 & VI \\
\hline 7 & $\begin{array}{l}\text { Keeping the animal on } \\
\text { a concrete floor }\end{array}$ & $\begin{array}{c}186 \\
(77.50)\end{array}$ & $\begin{array}{c}16 \\
(6.66)\end{array}$ & $\begin{array}{c}38 \\
(15.84)\end{array}$ & 388 & VII \\
\hline 8 & $\begin{array}{l}\text { Application of tincture } \\
\text { iodine to the belly of } \\
\text { calf after parturition }\end{array}$ & $\begin{array}{c}166 \\
(69.16)\end{array}$ & $\begin{array}{c}52 \\
(21.67)\end{array}$ & $\begin{array}{c}22 \\
(9.17)\end{array}$ & 384 & VIII \\
\hline 9 & $\begin{array}{l}\text { Practicing de-horning } \\
\text { in calf on proper time }\end{array}$ & $\begin{array}{c}121 \\
(50.41)\end{array}$ & $\begin{array}{c}102 \\
(42.50)\end{array}$ & $\begin{array}{c}17 \\
(7.09)\end{array}$ & 344 & IX \\
\hline 10 & $\begin{array}{l}\text { Keeping the animal } \\
\text { and newly born calf at } \\
\text { warm place just after } \\
\text { calving }\end{array}$ & $\begin{array}{c}104 \\
(43.34)\end{array}$ & $\begin{array}{c}80 \\
(33.33)\end{array}$ & $\begin{array}{c}56 \\
(23.33)\end{array}$ & 288 & $\mathrm{X}$ \\
\hline 11 & $\begin{array}{l}\text { Keeping of animal } \\
\text { loose in the shed }\end{array}$ & $\begin{array}{c}130 \\
(54.16)\end{array}$ & $\begin{array}{c}25 \\
(10.42)\end{array}$ & $\begin{array}{c}85 \\
(35.42)\end{array}$ & 285 & $\mathrm{XI}$ \\
\hline 12 & Animal castration & $\begin{array}{c}116 \\
(48.34)\end{array}$ & $\begin{array}{c}48 \\
(20.00)\end{array}$ & $\begin{array}{c}76 \\
(31.66)\end{array}$ & 280 & XII \\
\hline 13 & $\begin{array}{l}\text { Separation of pregnant } \\
\text { animal from the herd }\end{array}$ & $\begin{array}{c}93 \\
(38.75)\end{array}$ & $\begin{array}{c}90 \\
(37.50)\end{array}$ & $\begin{array}{c}57 \\
(23.75)\end{array}$ & 276 & XIII \\
\hline 14 & $\begin{array}{l}\text { Practicing weaning in } \\
\text { calves }\end{array}$ & $\begin{array}{c}98 \\
(40.83)\end{array}$ & $\begin{array}{c}78 \\
(32.50)\end{array}$ & $\begin{array}{c}64 \\
(26.67)\end{array}$ & 274 & XIV \\
\hline
\end{tabular}

Figures in parentheses indicate percentage 
Table.5 Distribution of different categories of respondents according to their adoption level of improved dairy farming practices

\begin{tabular}{|c|c|c|c|c|c|}
\hline \multirow{2}{*}{$\begin{array}{c}\text { Level of } \\
\text { adoption }\end{array}$} & Breeding & Feeding & Health care & Management & Overall IDFPs \\
\hline Low & 44 & 48 & 38 & 57 & 47 \\
& $(18.34)$ & $(20.00)$ & $(15.84)$ & $(23.75)$ & $(19.58)$ \\
\hline Medium & 159 & 164 & 170 & 123 & 149 \\
& $(66.25)$ & $(68.34)$ & $(70.83)$ & $(51.25)$ & $(62.09)$ \\
\hline High & 37 & 28 & 32 & 60 & 44 \\
& $(15.41)$ & $(11.66)$ & $(13.33)$ & $(25.00)$ & $(18.33)$ \\
\hline
\end{tabular}

Figures in parentheses indicate percentage

Similarly, Wallowing of animal in pond (403), practicing de-worming in calf (401), help taken from veterinarians during the sickness of animals (398), keeping the animal on a concrete floor (388), application of tincture iodine to the belly of calf after parturition (384) and practicing de-horning in calf on proper time (344) were occupied the ranks of $4^{\text {nd }}, 5^{\text {rd }}, 6^{\text {th }}, 7^{\text {th }}$, $8^{\text {th }}$ and $9^{\text {th }}$ respectively. The last $14^{\text {th }}$ rank was awarded to practicing weaning in calves with lowest adoption score (274). It may be concluded that almost all the respondents were having knowledge about importance of ventilated houses and adopted this practice with higher adoption score. While they had never taken care of artificial nurturing of newly born calf. Similar findings are reported by Satyarthi et al., (2003), Shiraj (2000) and Choudhary (1997).

Distribution of different categories of respondents according to their adoption level of improved dairy farming practices

Table 5 displays the result of level of adoption of improved dairy farming practices, the respondents were classifieds into low, medium and high adoption categories on the basis of cumulative square root frequency method. The data in Table 4.4.5 indicated that among dairy farmers the majority of the respondents $(66.25 \%)$ had medium level of adoption of breeding practices followed by $(15.41 \%)$ of the respondents and (18.34\%) of the respondents who had high level and low level of adoption of improved breeding practices. In case of feeding practices majority of the respondents $(68.34 \%)$ fell in medium level, followed by, low $(20.00 \%)$ and high (11.66\%) level of adoption. Regarding healthcare practices most of the respondents $(70.83 \%)$ were observed in medium category followed by low (15.84\%) and high (13.33\%) level of adoption of improved healthcare practices. As for as concerned the management practices majority of the respondents $(51.25 \%)$ in medium category, followed by high $(25.00 \%)$ and low (23.75\%) level of adoption. Majority of the respondents $(62.09 \%)$ had medium level of overall adoption of improved dairy farming practices, whereas, remaining respondents were 19.58 per cent in low and 18.33 per cent high level of adoption of overall improved dairy farming practices. The similar findings also reported by Imali et al., (1993), Kulshestra and Gawaskar (1994), Chaturvedi et al., (1997), Pandey and Yadav (2002), Satyarthi et al., (2003) and Srivastava et al., (2010).

It can be concluded from the above findings that majority of the respondents (62.09 per cent) had medium level of overall adoption. Extent of adoption of the improved dairy practices viz., Breeding Feeding, Healthcare and Management were found to be medium category 66.25 , $68.34,70.83$ and 51.25 respectively. Maximum adoption was found in case of management practices, whereas minimum adoption was found in case of healthcare practices. Therefore, recommended on the basis of findings that efforts should be made to convince the dairy 
farmers about the adoption of artificial insemination, pregnancy diagnosis, deworming, castration of male calves and other selected improved dairy farming practices. Besides, dairy farmers should be motivated for more adoption by organizing educational programmes, training classes and demonstrations. Simultaneously, avenues must be open in this area for efficient and economic marketing of milk at good price

\section{Acknowledgement}

The authors thankfully acknowledge Director and Advisor, National Dairy Research Institute, Karnal for providing facilities and valuable guidance for the research work.

\section{References}

Chaturvedi, M. A., Dilawar, G. and Gupta, S. 1997. Adoption of improved animal husbandry practices in Raipur district; M.Sc. Thesis, I. G. K. V., Chattisgarh.

Choudhary, S., and Kapoor, V. D. 1998. Adoption of improved feeding practices by buffalo owners of the ICDP, Karnal. Indian Research Journal of Extension Education.11 (108): 60-64.

Economic Survey of Haryana. (2015). Government of India

Imali, S. S., Desai, H. K., and Tomar, B. B. 1993. A study on the adoption of improved dairy farming practices by the farmers of Northern Haryana. M.Sc. (Ag.) Thesis (unpub.), NDU, Uttar pradesh.

Kulshreshta, B. B., and Gawaskar, A. J. 1994. Study on adoption of scientific dairy farming practices. Indian Journal of Extension Education. 58(1): 0639-9486.

Lomani, K. L. 1996. A study of the differential adoption of scientific dairy farming practices in Ludhiana District, Panjab, Ph.D. Thesis submitted to J. N. K. V., Madhya Pradesh

Menon, A. S. 2009. Differential adoption of scientific dairy farming practices and related constraints. Indian Research Journal of Extension Education. 9 (4): 4245.

Pande, B., and Yadav. N. 2002. A study on knowledge and adoption of improved dairy practicing women in Sirohi district of Rajasthan. M. Sc. (Agri.) Thesis, University of Agricultural Sciences, Bangalore.

Raisen; S.S., 1994. Study of existing dairy farming practices in Gujarat. Journal of Animal Science. 9(2): 56:70.

Satyarthi, P. N., 2003. A comparative study of adoption of dairy farm technologies between non-members and members of dairy cooperative village. India Journal of Animal Sciences. 55 (4): 401-407.

Shinde, K. 2001. Prospects in adoption of animal husbandry practices in Haryana. Ph.D. Thesis, L.L.R. Veterinary University, Hissar, Haryana.

Shiraj, S., Kumar, (2000). Adoption level of improved dairy farming practices by dairy farmers of Panjab. Indian Journal of Extension Education, 8 (6): 40-45.

Shukla, K. S., and Pathak, D. C. 1995. Differential adoption of improved dairy practices by small and marginal farmers, Indian Journal of Extension Education. 30(6\&7): 83.86

Srivastava, D. P., Mehta, P. N., and Nawale, J. D. 2010. Adoption of improved animal husbandry practices by owners of cross bred cattle under ICDP. Osmanabad, Maharashtra Journal of Extension Education. 4: 220-225.

\section{How to cite this article:}

Manish Kumar Singh, Awadhesh Kumar Singh and Kadian, K.S. 2018. Adoption of Improved Dairy Farming Practices by Dairy Farmers of Haryana. Int.J.Curr.Microbiol.App.Sci. 7(9): 36223629. doi: https://doi.org/10.20546/ijcmas.2018.709.450 